\title{
Peningkatan Infeksi Patogen Busuk Pangkal pada Bawang Putih oleh Meloidogyne dengan Variasi Kerapatan Inokulum
}

\section{Increased Infection of Basal Rot Pathogens on Garlic by Meloidogyne with Variations of Inoculum Density}

\author{
Novi Pujiastuti ${ }^{1)}$, Hadiwiyono ${ }^{2)}$, Subagiya ${ }^{2)}$
}

\begin{abstract}
Fusarium oxysporum $f$. sp. cepae (FOCe) causing basal rot of garlic is the main obstacle in improving garlic production. The presence of root knot nematode (Meloidogyne spp.) is thought to cause an increase in the disease was caused by FOCe. This research aimed to study the effect of the presence of Meloidogyne in increasing the disease severity of basal rot of garlic caused by FOCe and interactions between them. The research was conducted through surveys and experimental procedures. The survey was conducted to obtain preliminary data on the relationship between the disease severity of basal rot of garlic and the infection of Meloidogyne in soil. Experimental study were prepared using a complete randomized block design, with two factors consisting of three levels inoculum density. The first factor was FOCe and the second factor was Meloidogyne spp. The results showed that the presence of Meloidogyne could increase the disease severity of basal rot of garlic.
\end{abstract}

Keywords: garlic, basal rot, Fusarium oxysporum f. sp. cepae, Meloidogyne

\section{PENDAHULUAN}

Bawang putih termasuk komoditas pertanian yang memiliki nilai ekonomis tinggi. Permintaan terhadap bawang putih tiap tahun cenderung meningkat, tetapi produksi bawang putih belum dapat memenuhi permintaan tersebut. Kendala utama dalam produksi bawang putih adalah serangan Fusarium oxysporum f. sp. cepae penyebab penyakit busuk pangkal pada tanaman bawang putih (Widodo et al. 2008).

Fusarium oxysporum f.sp. cepae merupakan penyebab penyakit serius pada beberapa spesies Allium. Menurut Hadiwiyono dan Widono (2008), busuk pangkal bawang putih merupakan penyakit paling penting di pertanaman bawang putih di Tawangmangu sejak musim tanam tahun 2000. Selain faktor utama berupa patogen yang virulen, tingkat keparahan penyakit juga dipengaruhi oleh interaksi antara patogen dengan organisme lain yang berasosiasi dengan tanaman.

Salah satu interaksi paling penting antara nematoda dan tanaman adalah kemampuan beberapa nematoda untuk mempengaruhi resistensi tanaman. Nematoda parasit mempengaruhi hubungan inang antara tanaman dan patogen lain (Abuzar 2012). Meloidogyne yang lebih dikenal dengan root-knot nematode merupakan penyebab terjadinya puru atau bengkak akar pada berbagai tanaman. Menurut Mulyadi (2009), keberadaan nematoda puru akar (Meloidogyne spp.) menyebabkan terjadinya peningkatan insidens,

\footnotetext{
1) Undergraduate Student of Study Program of Agrotechnology, Faculty of Agriculture, Sebelas Maret University.

${ }^{2)}$ Lecturer of Study Program of Agrotechnology, Faculty of Agriculture, Sebelas Maret University.

Contact Author: subagiya@gmail.com
}

perkembangan, keparahan, dan kerusakan tanaman oleh $F$. oxysporum. Keberadaan nematoda puru akar (Meloidogyne spp.) diduga menyebabkan terjadinya peningkatan keparahan penyakit yang disebabkan oleh F. oxysporum.

Penelitian bertujuan untuk mempelajari pengaruh keberadaan Meloidogyne dalam meningkatkan keparahan penyakit busuk pangkal bawang putih yang disebabkan oleh $F$. oxysporum f. sp. cepae dan interaksi diantara keduanya.

\section{METODE PENELITIAN}

Penelitian ini telah dilaksanakan pada bulan Mei sampai September 2013 bertempat di Tawangmangu, Karanganyar dan di Laboratorium Hama dan Penyakit Tanaman Fakultas Pertanian Universitas Sebelas Maret Surakarta.

Bahan yang digunakan isolat $F$. oxysporum f.sp. cepae yang diperoleh dari bawang putih yang terinfeksi, isolat Meloidogyne, bibit bawang putih varietas Tawangmangu Baru, tanah steril dan pupuk, sedangkan alat yang digunakan meliputi pot plastik berdiameter $50 \mathrm{~cm}$, peralatan budidaya, serta peralatan ekstraksi Meloidogyne dan isolasi $F$. oxysporum f.sp. cepae.

Penelitian dilaksanakan melalui serangkaian prosedur survei dan eksperimen. Pelaksanaan penelitian diawali dengan pelaksanaan survei. Survei dilakukan dengan metode transek dengan petak pengamatan seluas $1.5 \mathrm{~m} \times 1.5 \mathrm{~m}$. Survei dilakukan untuk memperoleh data awal mengenai keterkaitan antara intensitas penyakit busuk pangkal bawang putih dengan jumlah Meloidogyne di lahan.

Penelitian eksperimen disusun menggunakan rancangan acak kelompok lengkap, dengan menggunakan dua faktor yang masing-masing terdiri dari tiga taraf. Faktor pertama $(F)$ adalah inokulasi $F$. oxysporum f.sp. cepae dengan tiga taraf kerapatan inokulum (tanpa inokulasi, $10^{3} \mathrm{spora} / \mathrm{ml}$ air, dan $10^{5}$ 
spora/ml air). Faktor kedua (M) adalah inokulasi Meloidogyne spp. dengan tiga taraf kerapatan inokulum (tanpa inokulasi, 3 masa telur, dan 5 masa telur), 1 masa telur Meloidogyne = 165 larva. Kombinasi perlakuan yang diulang sebanyak tiga kali ulangan. Inokulasi dilakukan saat tanaman berumur 7 hari setelah tanam.

Variabel pengamatan terdiri dari masa inkubasi, intensitas kelayuan dan busuk umbi, laju infeksi penyakit, AUDPC, dan jumlah akhir Meloidogyne.

Intensitas layu dan busuk umbi dihitung dengan menggunakan rumus sebagai berikut:

$$
\text { Intensitas Penyakit }=\frac{\sum(n x D)}{N x Z} \times 100 \%
$$

dengan $n=$ jumlah tanaman yang diamati menunjukkan skor tertentu; $v=$ skor untuk tanaman yang mengalami gejala kelayuan; $N=$ skor tertinggi; dan $Z$ = jumlah seluruh tanaman yang diamati.

Ketentuan skoring yang digunakan adalah $0=$ tanaman tidak menunjukan gejala; $1=1-25 \%$ daun layu/umbi busuk ; 2 = 26-50\% daun layu/umbi busuk; $3=51-75 \%$ daun layu/umbi busuk; dan $4=76-100 \%$ daun layu/umbi busuk.

Laju Infeksi Penyakit dihitung secara mingguan, menggunakan rumus sebagai berikut:

$$
r=\frac{2.3}{t}\left(\log \frac{1}{1-X t}\right)-\left(\log \frac{1}{1-X o}\right)
$$

dengan $r$ = laju infeksi penyakit (per unit per minggu); $t=$ interval waktu pengamatan (mingguan); $X O=$ proporsi penyakit pada awal pengamatan; dan $X t=$ proporsi penyakit pada pengamatan ke $t$.

Nilai Area of Under the Disease Progress Curve (AUDPC) diperoleh dari hasil pengamatan insidens penyakit. Dihitung dengan rumus:

$$
A U D P C=\sum_{n-1}^{i=1}\left[\frac{X i+X i+1}{2}\right] \times \mathrm{t}_{i+1}-\mathrm{t}_{i}
$$

dengan $x=$ insidens penyakit, dan $t=$ waktu pengamatan (minggu ke-1, 2, 3, dan seterusnya).

Analisis data survei dilakukan dengan menggunakan regesi linier sederhana antara jumlah populasi Meloidogyne dan intensitas penyakit busuk pangkal. Analisis data eksperimen pada penelitian ini menggunakan analisis ragam dengan uji $f$ taraf 0,05. Apabila terdapat beda nyata dilanjutkan dengan uji jarak berganda Duncan (Duncan's Multiple Range Test /DMRT).

\section{HASIL DAN PEMBAHASAN}

\section{Pengamatan Intensitas Penyakit Busuk Pangkal Bawang Putih dan Jumlah Meloidogyne di Lapangan}

Hasil analisis regresi linier sederhana antara intensitas penyakit busuk pangkal bawang putih dengan jumlah Meloidogyne, menunjukan bahwa terdapat hubungan antara jumlah Meloidogyne dengan intensitas penyakit busuk pangkal bawang putih di lahan.

Semakin banyak jumlah Meloidogyne di suatu lahan maka semakin tinggi tingkat intensitas penyakit busuk pangkal bawang putih yang terdapat di lahan tersebut (Gambar 1). Persamaan regresi yang terbentuk antara hubungan intensitas penyakit busuk pangkal bawang putih (y) dengan jumlah Meloidogyne (x) yang terdapat di lahan yaitu $y=5,309 x-5,206$.

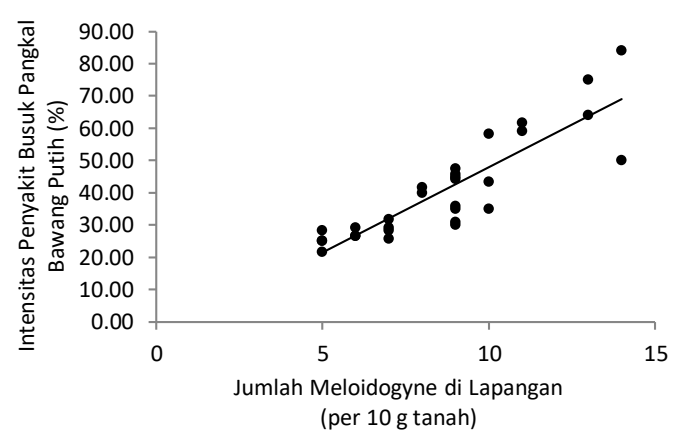

Gambar 1. Grafik intensitas penyakit busuk pangkal bawang putih dan jumlah Meloidogyne

\section{Masa Inkubasi Penyakit Busuk Pangkal Bawang Putih}

Periode (masa) inkubasi merupakan waktu antara permulaan infeksi patogen dengan timbulnya gejala yang pertama. Menurut Rauf dan Javaid (2013), gejala tanaman bawang putih yang terserang penyakit busuk pangkal batang adalah daun kuning dan layu, akar mati, dan umbinya membusuk. Hasil analisis ragam (Anova) menunjukkan bahwa pemberian perlakuan konsentrasi inokulum $F$. oxysporum f.sp. cepae berpengaruh sangat nyata $(P<0.01)$ terhadap masa inkubasi penyakit (Tabel 1). Hal yang sama juga ditunjukan pada perlakuan pemberian Meloidogyne yang juga memberikan pengaruh sangat nyata $(P<0.01)$ terhadap masa inkubasi penyakit (Tabel 2). Navas-Cort'es et al (2000) menyatakan bahwa, jumlah inokulum mempengaruhi keparahan penyakit dan masa inkubasi penyakit.

Tanaman tanpa inokulasi $F$. oxysporum f.sp. cepae juga menunjukan gejala terjangkit penyakit busuk pangkal bawang putih. Menurut Pamungkas et al (2012), umbi bawang putih yang berasal dari tanaman yang terserang penyakit busuk pangkal bawang putih, akan membawa inokulum patogen.

Tabel 1. Pengaruh kerapatan spora $F$. oxysporum f.sp. cepae terhadap masa inkubasi penyakit busuk pangkal bawang putih

\begin{tabular}{cc}
\hline $\begin{array}{c}\text { Kerapatan Spora } F . \\
\text { oxysporum f.sp. cepae }\end{array}$ & Masa Inkubasi (Hari) \\
\hline $10^{5} \mathrm{spora} / \mathrm{ml}$ & $14.78 \pm 1.34 \mathrm{a}$ \\
$10^{3} \mathrm{spora} / \mathrm{ml}$ & $21.00 \pm 7.13 \mathrm{~b}$ \\
Tanpa inokulasi & $36.56 \pm 3.57 \mathrm{c}$ \\
\hline
\end{tabular}

Keterangan: Angka yang diikuti dengan huruf yang sama menunjukkan tidak beda nyata pada DMRT taraf $5 \%$. 
Tabel 2. Pengaruh jumlah masa telur Meloidogyne terhadap masa inkubasi penyakit busuk pangkal bawang putih

\begin{tabular}{cc}
\hline $\begin{array}{c}\text { Jumlah Masa Telur } \\
\text { Meloidogyne }\end{array}$ & Masa Inkubasi (Hari) \\
\hline 5 masa telur & $27.22 \pm 10.17 \mathrm{a}$ \\
3 masa telur & $24.11 \pm 11.97 \mathrm{~b}$ \\
tanpa inokulasi & $21.00 \pm 11.74 \mathrm{c}$ \\
\hline
\end{tabular}

Keterangan: Angka yang diikuti dengan huruf yang sama menunjukkan tidak beda nyata pada DMRT taraf $5 \%$.

\section{Intensitas Kelayuan Penyakit Busuk Pangkal Bawang Putih}

Intensitas penyakit atau keparahan penyakit merupakan pengukuran luas serangan patogen yang didasarkan pada skor gejala penyakit akibat infeksi patogen ke tanaman. Perlakuan inokulasi $F$. oxysporum f.sp. cepae dan Meloidogyne berpengaruh sangat nyata $(P<0.01)$ terhadap intensitas kelayuan penyakit busuk pangkal bawang putih. Gambar 2 menunjukkan bahwa intensitas kelayuan pada semua perlakuan mengalami peningkatan disetiap minggunya, dengan intensitas tertinggi terdapat pada perlakuan jumlah inokulum tertinggi. Navas-Cort'es et al (2000) menyatakan bahwa peningkatan konsentrasi inokulum Fusarium mempercepat perkembangan gejala layu pada tanaman yang ditelitinya, sedangkan konsentrasi yang lebih rendah menunda ekspresi gejala layu.

Inokulasi Fusarium dan Meloidogyne mengakibatkan gejala layu yang lebih tinggi dibandingkan dengan inokulasi tunggal. Ganaie dan Khan (2011), menyatakan bahwa interaksi sinergis dari gabungan kedua patogen Meloidogyne dan fungi pada tanaman dapat terlihat dari nilai indeks kelayuan. Menurut Jiménez-Gasco et al. (2004), berdasarkan penelitian yang telah dilakukannya, konsentrasi inokulum Fusarium mempengaruhi persentase tanaman yang terserang. Peningkatan kepadatan inokulum nematoda dan jamur berkorelasi positif terhadap penyakit layu fusarium. Hal tersebut ditunjukkan dengan peningkatan terhadap insiden dan keparahan penyakit layu (Chindo et al, 2010).
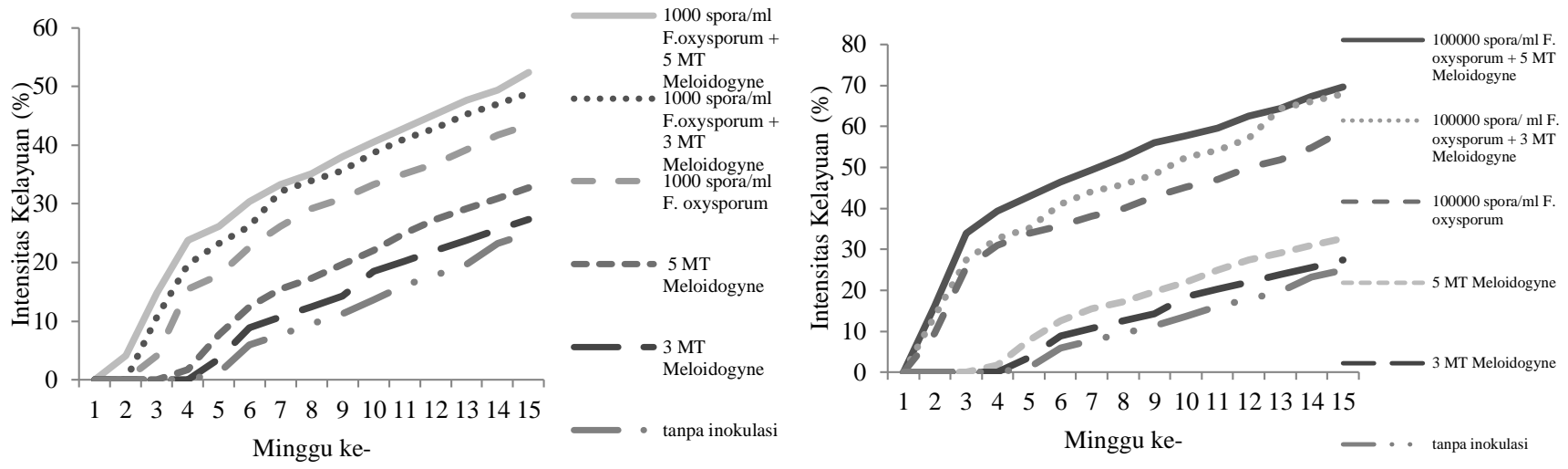

Gambar 2. Pengaruh inokulasi ganda F. oxysporum f. sp. cepae dan Meloidogyne terhadap rata-rata intensitas penyakit busuk pangkal bawang putih tiap minggu

\section{Laju Infeksi Penyakit Busuk Pangkal Bawang Putih}

Laju infeksi merupakan kecepatan infeksi patogen ke tanaman yang diukur dari perbedaan luas infeksi pada saat pengamatan awal dengan luas infeksi pada saat akhir pengamatan per satuan rentang waktu pengamatan. Perlakuan inokulasi $F$. oxysporum f.sp. cepae dan Meloidogyne berpengaruh sangat nyata $(P<0.01)$ terhadap laju infeksi penyakit busuk pangkal bawang putih (Gambar 3). Pemberian inokulum Meloidogyne artiellia dan F. oxysporum yang tinggi mempercepat laju perkembangan penyakit layu pada tanaman (Castillo et al, 2003). Gambar 4 menunjukkan bahwa laju infeksi penyakit cenderung menurun pada tiap minggunya. Hal tersebut diakibatkan karena tanaman membentuk suatu sistem perlawanan, untuk mencegah invasi patogen yang semakin parah ke seluruh jaringan tanaman (NavasCort'es et al, 2000).

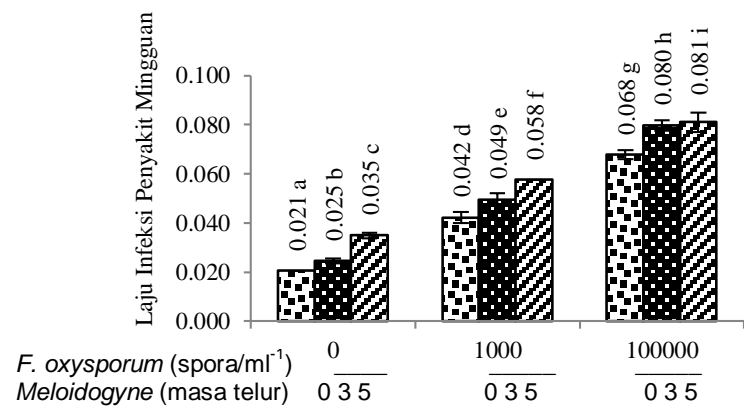

Keterangan: Angka yang diikuti dengan huruf yang sama tidak berbeda nyata pada DMRT taraf $5 \%$

Gambar 3. Pengaruh inokulasi ganda F. oxysporum f. sp. cepae dan Meloidogyne terhadap laju infeksi penyakit busuk pangkal bawang putih mingguan 


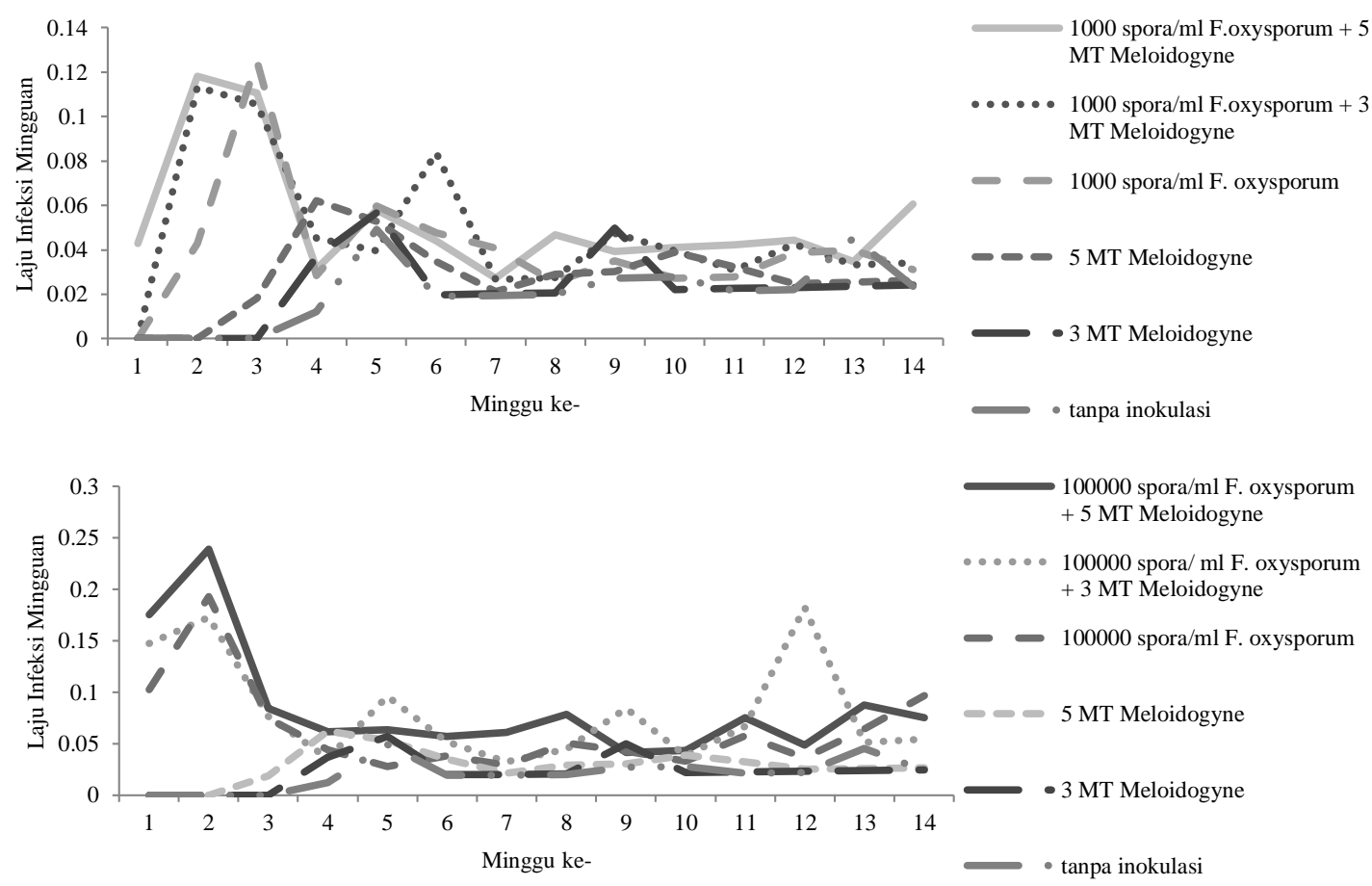

Gambar 4. Pengaruh inokulasi ganda F. oxysporum f. sp. cepae dan Meloidogyne terhadap rata-rata laju infeksi penyakit busuk pangkal bawang putih tiap minggu

\section{Area of Under the Disease Progress Curve (AUDPC) Penyakit Busuk Pangkal Bawang Putih}

Pengaruh inokulasi ganda secara keseluruhan dapat ditunjukan oleh perkembangan penyakit per satuan waktu, melalui model luas daerah di bawah kurva perkembangan penyakit atau Area of Under the Disease Progress Curve (AUDPC). Perlakuan inokulasi $F$. oxysporum f.sp. cepae dan Meloidogyne berpengaruh sangat nyata $(P<0.01)$ terhadap AUDPC penyakit busuk pangkal (Gambar $5)$.

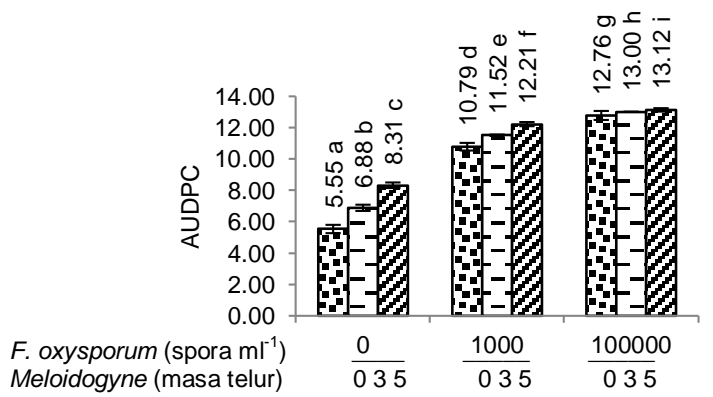

Keterangan: Angka yang diikuti dengan huruf yang sama tidak berbeda nyata pada DMRT taraf $5 \%$

Gambar 5. Pengaruh inokulasi ganda $F$. oxysporum f. sp. cepae dan Meloidogyne terhadap AUDPC penyakit busuk pangkal bawang putih
Semakin tinggi jumlah inokulum maka angka AUDPC semakin besar. Hal yang sama juga diungkapkan oleh Chawla et al (2012) yang menyatakan bahwa jumlah inokulum Fusarium dan Meloidogyne secara langsung mempengaruhi tingkat keparahan, dan luas daerah di bawah kurva perkembangan penyakit.

\section{Intensitas Busuk Umbi Penyakit Busuk Pangkal Bawang Putih}

Serangan patogen $F$. oxysporum f.sp. cepae penyebab penyakit busuk pangkal bawang putih, secara langsung mempengaruhi hasil bawang putih karena umbi menjadi busuk dan berwarna kuning coklat.

Perlakuan inokulasi $F$. oxysporum f.sp. cepae dan Meloidogyne berpengaruh sangat nyata $(P<0.01)$ terhadap intensitas busuk umbi penyakit busuk pangkal bawang putih. Perbedaan intensitas busuk umbi akibat pengaruh pemberian jumlah inokulum $F$. oxysporum f.sp. cepae dan Meloidogyne yang berbeda tertera dalam Gambar 6 .

\section{Jumlah Populasi Akhir Meloidogyne}

Populasi Meloidogyne di hitung per $10 \mathrm{~g}$ tanah. Hasil analisis ragam (Anova) menunjukkan bahwa pemberian perlakuan konsentrasi inokulum $F$. oxysporum f.sp. cepae dan Meloidogyne berpengaruh sangat nyata $(P<0.01)$ terhadap jumlah populasi akhir Meloidogyne (Gambar 7). 


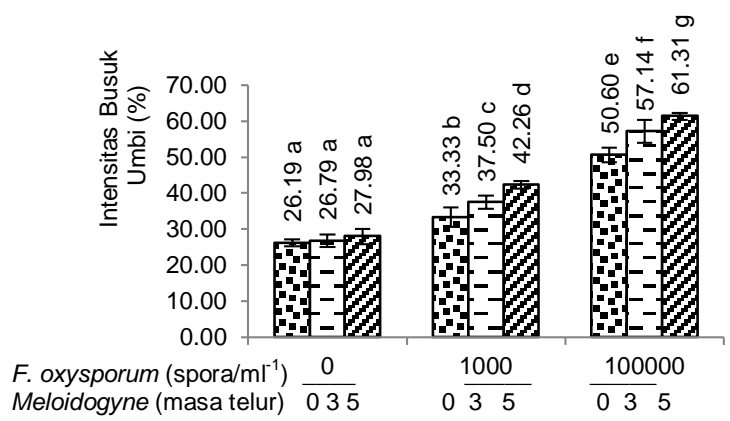

Keterangan: Angka yang diikuti dengan huruf yang sama tidak berbeda nyata pada DMRT taraf 5\%

Gambar 6. Pengaruh inokulasi Ganda F. oxysporum f. sp. cepae dan Meloidogyne terhadap intensitas busuk umbi penyakit busuk pangkal bawang putih.

Keberadaan F. oxysporum f.sp. cepae mempengaruhi keberadaan Meloidogyne di tanah. Hal yang sama juga didapatkan pada penelitian yang dilakukan oleh Jumjunidang et al (2009) yang menyatakan bahwa terjadi penurunan jumlah populasi akhir dibandingkan dengan populasi awal inokulasi. Menurut Castillo et al (2003), Penurunan jumlah populasi Meloidogyne disebabkan karena menurunnya reproduksi Meloidogyne akibat kerusakan akar yang terserang oleh jamur. Persaingan antara dua organisme ini menyebabkan berkurangnya luas akar untuk infeksi, sehingga Meloidogyne tidak dapat bereproduksi.

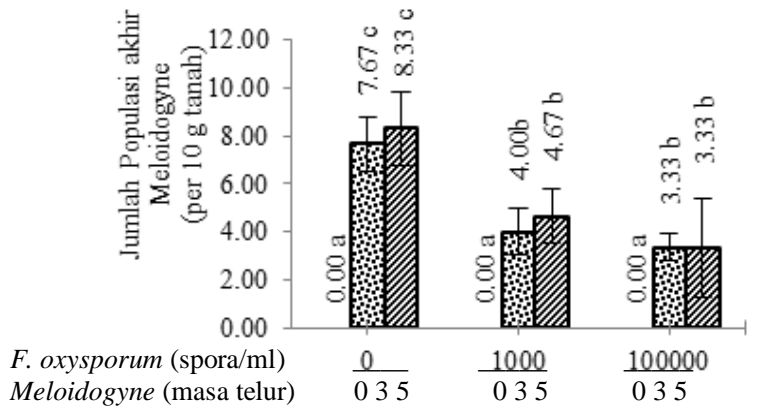

Keterangan: Angka yang diikuti dengan huruf yang sama tidak berbeda nyata pada DMRT taraf $5 \%$

Gambar 7. Pengaruh inokulasi Ganda F. oxysporum f. sp. cepae dan Meloidogyne terhadap jumlah populasi akhir Meloidogyne

\section{KESIMPULAN DAN SARAN}

\section{Kesimpulan}

1. Keberadaan Meloidogyne dapat meningkatkan intensitas penyakit busuk pangkal bawang putih yang disebabkan oleh $F$. oxysporum f. sp. cepae.
2. Jumlah Meloidogyne yang tinggi diimbangi dengan keberadaan $F$. oxysporum f. sp. cepae di tanah dapat meningkatkan intensitas penyakit busuk pangkal dan menurunkan produksi umbi bawang putih.

\section{Saran}

Perlu dilakukan penelitian lebih lanjut dengan variasi kerapatan inokulum $F$. oxysporum f.sp. cepae, dan Meloidogyne yang lebih beragam. Untuk mengetahui intensitas penyakit busuk pangkal pada variasi kerapatan kedua inokulum.

\section{DAFTAR PUSTAKA}

Abuzar S. 2012. Management of root-knot nematode, Meloidogyne incognita-wilt fungus, Fusarium oxysporum disease complex of green gram, Vigna radiata. IJARS 1(2): 1-10.

Castillo P, Navas-Cortés JA, Gomar-Tinoco D, Vito MD, Jiménez-Díaz RM. 2003. Interaction between Meloidogyne artiellia, the cereal and legume RootKnot nematode, and Fusarium oxysporum f.sp. ciceris Race 5 in Chickpea. Phytopathology 93(12): 1513-1523.

Chawla S, Woodward JE, Wheeler TA, Wright RJ. 2012. Effect of Fusarium oxysporum f.sp. vasinfectum inoculum density, Meloidogyne incognita and Cotton Cultivar on Fusarium Wilt Development. Texas J Agric Nat Res 24: 46-56.

Chindo PS, Shebayan JAY Marley PS. 2010. Effect of Pre-Emergence Herbicide on Meloidogyne spp. and Fusarium wilt of Tomato in Samaru, Zaria, Nigeria. J Agric Res 48(4): 489-495.

Ganaie MA, Khan TA. 2011. Studies on the Interactive effect of Meloidogyne incognita and Fusarium solani on Lycopersicion esculentum, Mill. Int J Bot 10: $1-4$.

Jiménez-Gasco MM, Navas-Cortés JA, Jiménez-Díaz RM. 2004. The Fusarium oxysporum f. $s p$. ciceris/Cicer arietinum pathosystem: A case study of the evolution of plant-pathogenic fungi into races and pathotypes. Int Micro 7: 95-104.

Jumjunidang, Andinata Y, Sulyanti E. 2009. The effect of initial population of Radopholus similis to induce Fusarium oxysporum f.sp. cubense Race 4 on Banana. cv. Ambon Hijau. Agriv 13(1): 48-56.

Hadiwiyono, Widono S. 2008. Hubungan faktor lingkungan tanah terhadap intensitas busuk pangkal bawang putih di Tawangmangu. Agrin 12(1): 15-22.

Mulyadi. 2009. Nematologi pertanian. Yogyakarta (ID): Gadjah Mada University Press.

Navas-Cort'es JA, Alcal'a-Jim'enez AR, Hau B Jim'enez-D'iaz RM. 2000. Influence of inoculum density of races 0 and 5 of Fusarium oxysporum f. $\mathrm{sp}$. ciceris on development of Fusarium wilt in chickpea cultivars. Europ J PI Path 106: 135-146.

Pamungkas YH, Hadiwiyono, Fatawi ZD. 2012. Relationship of visual symptoms to pathogens

Peningkatan Infeksi Patogen Busuk Pangkal pada Bawang Putih oleh Meloidogyne................

Novi Pujiastuti, Hadiwiyono, Subagiya 
infection Fusarium oxysporum f.sp. Cepae on Garlic Seed. J Agron Res 1(2): 35-40.

Rauf S, Javaid A. 2013. Antifungal activity of different extracts of Chenopodium album against Fusarium oxysporum f. sp. cepae, the cause of onion basal Rot. Int J Agric Biol 15(2): 367?371.
Widodo, Kondo N, Kobayashi K, Ogoshi A. 2008. Vegetative compatibility groups within Fusarium oxysporum f. sp. cepae in Hokkaido-Japan. J Mikro Ind 2(1): 39-43. 